\section{The Geological Society of America (GSA)}

\author{
http://www.geosociety.org
}

The Geological Society of America (GSA) is a broad, unifying scientific society:

- Fostering the human quest for understanding Earth, planets, and life;

- Catalyzing new scientific ways of thinking about natural systems; and

- Applying geoscience knowledge and insight to human needs and aspirations and stewardship of the Earth.

Specifically, GSA's mission is to advance the geosciences, to enhance the professional growth of its 17,000 members, and to promote the geosciences in the service of humanity worldwide.

GSA provides geoscientists from all employment sectors - academic, government, and industry - with a vehicle for expressing core professional values related to science, stewardship, and service. The Society is also a venue for establishing and maintaining professional relationships that span a lifetime.

\section{A brief history of GSA}

Founded in 1888 in Ithaca, New York, the Society is an offshoot of the American Association for the Advancement of Science (AAAS). GSA was formed in recognition of the rapid growth of geology as a science, and the need for a forum dedicated to this new area of scientific inquiry. Its founders envisioned the Society disseminating results of geologic studies and conducting meetings for the presentation and discussion of geologic research. These activities remain at the core of GSA's contemporary mission.

The Society moved to its current home in Boulder, Colorado, in 1967, where its operations and headquarters staff of approximately 50 people are housed and its collections of rock, mineral, and fossil specimens are displayed.

\section{Programs, services, and products}

GSA's primary activities are:

Publishing current scientific information in print, online, and compact disc formats.

The Society's two highly respected monthly journals, the Geological Society of America Bulletin and Geology, are primary vehicles for publication of academic research in the geosciences. GSA also co-publishes Environmental and Engineering Geoscience with the Association of Engineering Geologists. Other publications include special papers,

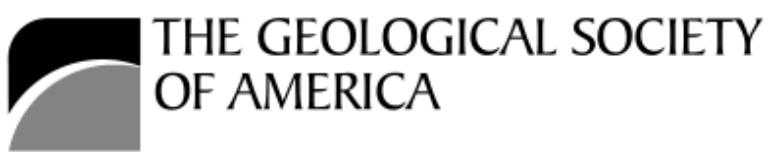

\author{
SCIENCE - STEWARDSHIP - SERVICE
}

GSA journals from 1988 forward are available online. The Society is presently working with other scientific organizations to establish a searchable, full-text, online database for group member's publications.

In addition, GSA cooperates with the Soil Science Society of America on its Vadose Zone Journal. The Society also offers the IAH Hydrogeology Journal and AGI's Geotimes to its members through special agree-

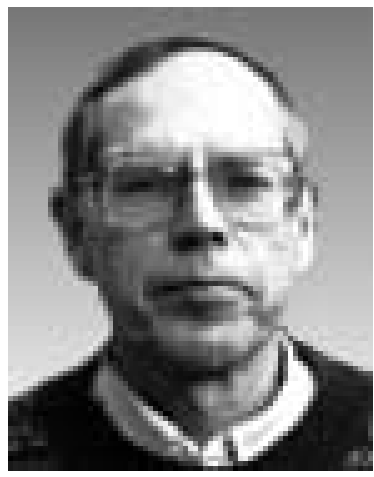

Dr. B. Clark Burchfiel, President of the Geological Society of America

Conducting scientific meetings that present the latest in geoscience research.

Approximately 6000 geoscientists attend GSA's annual meeting each fall, where more than 3000 scientific papers are presented in symposia and technical sessions; the 2003 annual meeting will take place Nov. 2-5 in Seattle, Washington. Smaller meetings, organized by Section (defined by geographical areas of the U.S.) are held each spring. Division (area of specialization) meetings are also held each year.

Penrose Conferences, named in honor of R. A. F. Penrose, Jr., a GSA benefactor, were established in 1969. These small, prestigious conferences are intended to accelerate scientific advances through the development of emerging scientific ideas in the geosciences.

Helping teachers, students, and policymakers understand and make informed decisions about complex environmental, economic, and social issues, of which the geosciences are an integral component.

GSA's Education and Outreach programs foster public awareness and understanding of geoscience issues and provide support for K-16 teachers. Assistance for GSA student members is available through research grants and mentoring programs. Through the GeoCorps America ${ }^{\mathrm{TM}}$ Program, GSA helps to place geoscientists-students, professionals, and retirees-in temporary positions with the National Park Service and the USDA Forest Service. In partnership with the 


\section{Enhancing the professional growth of members.}

The Society coordinates professional education and career enhancement activities for geoscientists, including research grants, short courses, field trips, field forums, and Penrose Conferences.

In addition, GSA recognizes outstanding scientific contributions through a number of awards. The Society's major annual awards are:

- The R.A.F. Penrose, Jr., Medal, awarded in recognition of eminent research in pure geology. It honors outstanding original contributions or achievements that mark a decided advance in the science of geology.

- The Arthur L. Day Medal, awarded for outstanding contribution to geologic knowledge through the application of physics and chemistry to geologic problems.

- The Donath Medal, awarded to a young scientist for outstanding achievement and contribution to geologic knowledge. A cash prize accompanies this award.

- The Public Service Medal, in honor of Eugene and Carolyn Shoemaker, awarded to recognize the enhancement of geoscience understanding outside the geoscience community.

\section{New directions}

Much of today's exciting earth, ocean, and environmental science is interdisciplinary in nature; it is happening at the interfaces where geoscience overlaps with the work of other scientific disciplines. The Geological Society of America is committed to pursuing this integrative, interdisciplinary science in its meetings and publications. We are also committed to doing so with a global focus, in partnership with other geoscience societies around the world.

GSA is an affiliated organization of the IUGS. We help support Geoindicators, an IUGS program for identifying indicators of environmental health around the world.

We have established working relationships with the Geological Society of London, the Geological Association of Canada, the Geological Society of Australia, the Geological Society of South Africa, and the International Association of Hydrogeologists. These connections between societies are intended to develop venues for international cooperation. GSA further seeks to establish relations with earth science societies from developing countries in order to assist and foster development of the geosciences on a worldwide basis.

A case in point was a joint meeting held in 2001 with the Geological Society of London titled Earth System Processes. This scientifically successful meeting generated a great deal of enthusiasm and we intend to build on our experience by offering Earth System Processes II in the summer of 2005. Still in the early planning stages, major themes include Earth system evolution, Earth system linkages, and the future of humankind in the Earth system.

GSA is also committed to facilitating the transfer of geoscience knowledge to applied scientists and others in need of such information in their work. This fall, for example, GSA is sponsoring a meeting called Watershed Impacts of Wildland Fire-Understanding and Mitigation. Convened in partnarchin with a calect oroun of other acenciatione and onvarn. group of professionals who are responsible for making science-based decisions to protect watershed resources.

\section{How GSA is organized}

The Society's elected officers provide overall governance of GSA. The Council consists of 16 members, 5 of whom serve on the Executive Committee.

GSA's 6 geographic Sections have their own governance boards and meetings. In addition, 30 specialized geoscience organizations are formally associated or allied with GSA; they assist in developing the extensive scientific program of the Society's annual meeting.

Members have access to 13 GSA Divisions defined by scientific specialty: archaeological geology, coal geology, engineering geology, geobiology and geomicrobiology, geophysics, geoscience education, history of geology, hydrogeology, limnology, planetary geology, quaternary geology and geomorphology, sedimentary geology, and structural geology and tectonics. A 14th Division, international, provides a forum for global scientific exchange.

These Divisions facilitate communication and education among scientists within disciplines and facilitate cross-disciplinary activity within the Society. They also help develop the technical program for GSA's annual meeting, facilitate student participation in meetings, and help fund student research.

\section{How GSA is supported}

Member dues, meeting fees, and the sale of publications support the work of the Society. In 1931, the Society received a bequest from R.A.F. Penrose, Jr., a noted geologist and explorer, which generated an endowment fund. In addition, the GSA Foundation actively raises funds for research grants, achievement awards, special projects, and certain GSA publications. Contributions to support the work of this expanding nonprofit organization are welcome.

\section{GSA contacts}

John W. Hess, Executive Director, GSA

jhess@geosociety.org

Tom Fouch, President, GSA Foundation tfouch@geosociety.org

\section{GSA website}

www.geosociety.org

\section{Dr. B. Clark Burchfiel}

President, Geological Society of America, and

Professor, Department of Earth and Planetary Science, Massachusetts Institute of Technology,

Cambridge, MA,

USA 